\title{
Pilgrimage in Islam: Traditional and Modern Practices
}

\author{
Sophia Rose Arjana \\ London: Oneworld Publications, 2017. 288 pages.
}

Pilgrimage in Islam is a religious act wherein Muslims leave their homes and spaces and travel to another place, the nature, geography, and dispositions of which they are unfamiliar. They carry their luggage and belongings and leave their own spaces to receive the blessings of the dead, commemorate past events and places, and venerate the elect. In Pilgrimage in Islam, Sophia Rose Arjana writes that "intimacy with Allah is achievable in certain spaces, which is an important story of Islamic pilgrimage". The devotional life unfolds in a spatial idiom.

The introductory part of the book reflects on how pilgrimage in Islam is far more complex than the annual pilgrimage (hajj), which is one of the basic rites and obligations of Islam beside the formal profession of faith (kalima); prayers (șalāt); fasting (șawm); and almsgiving (zakāt). More pilgrims throng to Karbala, Iraq, on the Arbaeen pilgrimage than to Mecca on the Hajj, for example, but the former has received far less academic attention. The author expands her analytic scope to consider sites like Konya, Samarkand, Fez, and Bosnia, where Muslims travel to visit countless holy sites (mazarāt), graves, tombs, complexes, mosques, shrines, mountaintops, springs, and gardens to receive the blessings (baraka) of saints buried there. She reflects on broader methodological and theoretical questionshow do we define religion? - through the diversity of Islamic traditions about pilgrimage. 
Arjana writes that in pilgrimage-something which creates spaces and dispositions-Muslim journeys cross sectarian boundaries, incorporate non-Muslim rituals, and involve numerous communities, languages, and traditions (the merging of Shia, Sunni, and Sufi categories) even to "engende $[\mathrm{r}]$ a syncretic tradition". This approach stands against the simplistic scholarship on "pilgrimage in Islam", which recourses back to the story of the Hajj. Instead, Arjana borrows a notion of 'replacement hajjs' from the German orientalist Annemarie Schimmel, to argue that ziyārat is neither a sectarian practice nor antithetical to Hajj.

In the first chapter, Arjana presents "pilgrimage in Islam" as an open, demonstrative and communicative category. The extensive nature of the 'pilgrimage' genre is presented through documenting spaces and sites, geographies, and imaginations, and is visualized through architectural designs and structures related to ziyārat, like those named qubba, mazār (shrine), qabr (tomb), darih (cenotaph), mashhad (site of martyrdom), and maqām (place of a holy person).

In the second chapter, the author continues the theme of visiting sacred pilgrimage sites like "nascent Jerusalem", Mecca, and Medina. Jerusalem offers dozens of cases of the 'veneration of the dead' (historically and archaeologically) which, according to Arjana, characterizes much of Islamic pilgrimage. The third chapter explains rituals, beliefs, and miracles associated with the venerated bodies of the dead, including Karbala (commemorating the death of Hussein in $680 \mathrm{CE}$ ), 'Alawi pilgrimage, and pilgrimage to Hadrat Khidr, which blur sectarian lines of affiliation. Such Islamic pilgrimage is marked by inclusiveness and cohabitation.

The fourth chapter engages dreams, miracles, magical occurrences, folk stories, and experiences of clairvoyance (firāsat) and the blessings attached to a particular saint or wali ("friend of God"). This makes the theme of pilgrimage "fluid, dynamic and multi-dimensional," as shown in Javanese (Indonesian) pilgrimage where tradition is associated with Islam but involves Hindu, Buddhist and animistic elements. This chapter cites numerous sites that offer fluid spaces for the expression of different identities, the practice of distinct rituals, and cohabitation of different religious communities through the idea of "shared pilgrimage".

The fifth and final chapter shows how technologies and economies inflect pilgrimage. Arjana discusses the commodification of "religious personalities, traditions and places" and the mass production of transnational pilgrimage souvenirs, in order to focus on the changing nature of Islamic pilgrimage in the modern world through "capitalism, mobility and tech- 
nology". The massive changes wrought by technological developments are evident even from the profusion of representations of Hajj, as through pilgrims' photos, blogs, and other efforts at self-documentation. The symbolic representation of the dead through souvenirs makes the theme of pilgrimage more complex. Interestingly, she then notes how "virtual pilgrimage" or "cyber-pilgrimage" forms a part of Islamic pilgrimage in our times, amplifying how pilgrimage itself is a wide range of "active, ongoing, dynamic rituals, traditions and performances that involve material religions and imaginative formations and spaces."

Analyzing religious texts alone will not yield an adequate picture of pilgrimage in Islam, Arjana concludes. Rather one must consider texts alongside beliefs, rituals, bodies, objects, relationships, maps, personalities, and emotions. The book takes no normative position on whether the $z i$ yārat visitation is in fact a bid'ah (heretical innovation), as certain Muslim orthodoxies have argued. The author invokes Shahab Ahmad's account of how aspects of Muslim culture and history are seen as lying outside Islam, even though "not everything Muslims do is Islam, but every Muslim expression of meaning must be constituting in Islam in some way". The book is a solid contribution to the field of pilgrimage and Islamic studies, and the author's own travels and visits to the pilgrimage sites make it a practical contribution to religious studies.

Nazar Ul Islam Wani, $\mathrm{PhD}$ Assistant Professor, Department of Higher Education

Jammu and Kashmir, India 